\title{
Influence of bacteria on phytoplankton cell mortality with phosphorus or nitrogen as the algal-growth-limiting nutrient
}

\author{
Corina P. D. Brussaard ${ }^{1, *}$, Roel Riegman ${ }^{2}$ \\ ${ }^{1}$ Department of Microbiology, University of Bergen, Jahnebakken 5, N-5020 Bergen, Norway \\ ${ }^{2}$ Department of Biological Oceanography, Netherlands Institute for Sea Research, PO Box 59, 1790 AB Den Burg, Texel, \\ The Netherlands
}

\begin{abstract}
The effects of bacteria on phytoplankton mortality were studied with phosphorus or nitrogen as the algal-growth-limiting nutrients. Experiments were performed with the diatom Ditylum brightwellii using batch cultures, steady state continuous cultures and batch-mode cultures which were starved for the limiting nutrient after being preconditioned in a chemostat. With phosphorus limiting algal growth, the specific death rates of $D$. brightwellii generally increased upon bacterial inoculation. Bacteria enhanced algal mortality very likely due to competition with $D$. brightwellii for the limiting phosphate. With nitrogen as the algal-growth-limiting nutrient, however, the presence of bacteria had either no pronounced effect on or led to a reduction of the specific death rates of $D$. brightwellii. Remineralized ammonium was probably partly utilized by $\mathrm{N}$-starved cells of $D$. brightwellii, leading to reduced death rates of the algal cells. Bacteria thus indirectly prolonged survival of $D$. brightwellii populations under $N$ starvation. This study shows that bacteria can affect phytoplankton survival, which in turn may influence algal species succession. The degree of bacterial influence on algal death kinetics depends largely on the type of nutrient limiting algal growth and on the culture conditions.
\end{abstract}

KEY WORDS: Algal cell mortality - Ditylum brightwellii - Bacteria $\cdot \mathrm{N}$ and P deficiency Starvation

\section{INTRODUCTION}

In the field, phytoplankton populations experience loss of cells due to grazing, sinking and cell lysis. Under axenic culture conditions, algal cell lysis was found to be directly affected by the degree of nutrient deficiency (Brussaard et al. 1997). However, phytoplankton under natural growth conditions will have to compete for the growth-limiting nutrient with bacteria. Laboratory work by Currie \& Kalff (1984) and Bratbak (1987) suggested that bacteria are better competitors for inorganic phosphorus than algae. Bratbak (1987) found that the diatom Skeletonema costatum is negatively affected by bacterial activity under phosphorus depletion. Small bacteria, with a higher surface:volume ratio, have been reported to have the highest

•E-mail: corina.brussaard@uib.im.no affinity for the limiting dissolved orthophosphate (Thingstad et al. 1993). Accordingly, bacteria would be also more efficient competitors for ammonium, but whether bacteria also promote extra algal mortality when ammonium is the algal-growth-limiting substrate is still unknown.

Under ammonium or phosphate limitation, bacteria will only be superior to phytoplankton when organic carbon is present in sufficiently high amounts to prevent C limitation (Bratbak \& Thingstad 1985, Rothhaupt 1992, Kirchman 1994, Ietswaart \& Flynn 1995). Bacterial growth rates in marine ecosystems are often considered to be carbon rather than mineral nutrient limited (Bratbak \& Thingstad 1985, Kirchman et al. 1990, Brussaard et al. 1995). Besides exudation of organic components, interpreted as overflow of photosynthetically fixed carbon (photosynthetic extracellular release, PER; Mague et al. 1980, Bjørnsen 1988, Myklestad et al. 1989, Obernosterer \& Herndl 1995), 
algal cellular components released through cell lysis may be an important $C$ source for bacteria. Several field studies suggested that phytoplankton cell lysis products are potential $\mathrm{C}$ sources for bacteria, allowing balancing of their C budgets (Lancelot \& Billen 1985, Riemann \& Søndergaard 1986, Christoffersen et al. 1990. Brussaard et al. 1996). Laboratory studies on microbial decomposition of phytoplankton cells showed rapid mineralization rates (Fukami et al. 1981, Newell et al. 1981, Garber 1984, Hansen et al. 1986, Biddanda 1988). Bacterial mineralization of the relatively $\mathrm{N}$ - and P-rich lysed algal cellular components (Garber 1984, Caron et al. 1988, Jürgens \& Güde 1990, Goldman \& Dennett 1991) might also be an important process to supply algae with ammonium or phosphate, potentially influencing algal survival and species succession under nutrient deficiency.

This report presents data on the bacterial influence on phytoplankton cell mortality with either phosphorus $(\mathrm{P})$ or nitrogen $(\mathrm{N})$ as the algal-growth-limiting substrate. The experiments were performed with algal populations in batch cultures, in steady state continuous cultures, and with algal populations precultured in continuous cultures before being starved by switching off the medium supply. Batch cultures start with high concentrations of inorganic nutrients, which may resemble early spring bloom situations typical for temperate waters as argued by Bratbak (1987). In field situations, algae may also encounter prolonged periods of nutrient limitation and exhaustion (e.g. summer periods in coastal areas or oligotrophic waters). Such conditions are not well represented by ordinary batch cultures in which the physiological state of the algal cells constantly changes, but are better mimicked by nutrient-limited continuous cultures and by nutrientstarvation experiments with algal cultures preconditioned under nutrient limitation in continuous cultures.

\section{MATERIAL AND METHODS}

Batch culture systems. Batch culture experiments were performed with the axenic diatom Ditylum brightwellii (West) Grunow (\#358 Bigelow culture collection). During earlier experiments with this axenic $D$. brightwellii strain, no virus-like particles were observed extra- and intracellularly using transmission electron microscopy. To create xenic cultures of $D$. brightwellii (unialgal cultures containing bacteria), axenic cultures $(75 \mathrm{ml}$ each) were inoculated directly at the start of the experiments with a mixed community of marine bacteria. The latter was obtained from xenic cultures of $D$. brightwellii (originally isolated from Dutch coastal waters) at the end of the exponential phase by filtration through a sterile glass fiber filter
(GF/C Whatman, approximately $50 \%$ of total bacterial cells passed through the filter). The filtrate $(5 \mathrm{ml})$ was used as bacterial inoculum for the axenic culture of $D$. brightwellii. The mixed bacterial community (dominated by rods) thus consisted of a consortium of bacterial species presumably adapted to the specific culture conditions. The concentrations of bacteria at the start of the experiments were between 0.25 and $0.4 \times 10^{6}$ $\mathrm{ml}^{-1} \approx 20$ to $30 \mathrm{ng} \mathrm{C} \mathrm{ml}^{-1}$, using a conversion factor of

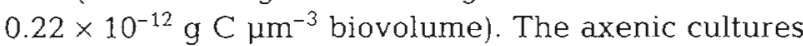
received $5 \mathrm{ml}$ of $0.2 \mu \mathrm{m}$ filtrate (sterile cellulose acetate disposable filters, Schleicher \& Schuell) containing no bacteria. No heterotrophic nanoflagellates grew in the cultures.

Because $\mathrm{pH}$ values varied between 8.0 and 8.7 in these batches, the experiments were repeated including cultures buffered with $20 \mathrm{mM}$ HEPES at pH $8.0 \pm$ 0.1 . This $\mathrm{pH}$ range had no significant effect on algal growth and mortality under either phosphate, ammonium or nitrate depletion (for all limitations $p>0.1$; data not shownj. Time interval between the duplicate unbuffered experiments was 1 mo. A list of culture conditions is presented in Table 1.

Media were based on aged, nutrient-poor, $0.2 \mu \mathrm{m}$ filtered, autoclaved seawater from the Central North Sea, acidified with $\mathrm{HCl}(\mathrm{pH}<3.5)$. The algal-growthlimiting factor was either $\mathrm{NH}_{4}^{+}$(concentration at the start of the experiments was $15 \mu \mathrm{M}$ ), $\mathrm{NO}_{3}{ }^{-}$(starting concentration $15 \mu \mathrm{M}$ ) or $\mathrm{PO}_{4}{ }^{3-}$ (starting concentrations 10 and $2.5 \mu \mathrm{M}$ ). Concentrations of the other macronutrients in the sterile medium were $2.7 \mathrm{mM} \mathrm{NaHCO}$, $150 \mu \mathrm{M} \mathrm{Na}_{2} \mathrm{SiO}_{3} \cdot 9 \mathrm{H}_{2} \mathrm{O}$, and either $300 \mu \mathrm{M} \mathrm{N}(150 \mu \mathrm{M}$ $\mathrm{NH}_{4} \mathrm{Cl}$ and $150 \mu \mathrm{M} \mathrm{NaNO}_{3}$ ) or $25 \mu \mathrm{M} \mathrm{NaH} \mathrm{PO}_{4}{ }^{3-}$, depending on the type of limiting nutrient. The basic medium was enriched with micronutrients and vitamins according to Brussaard et al. (1997). The $\mathrm{pH}$ of the medium was aseptically adjusted to $8.0 \pm 0.1$. Light was provided in a $16 / 8 \mathrm{~h} \mathrm{light/dark} \mathrm{cycle} \mathrm{at} \mathrm{a} \mathrm{density} \mathrm{of}$ 100 to $125 \mu \mathrm{mol}$ photons $\mathrm{m}^{-2} \mathrm{~s}^{-1}$. Temperature was kept at $13^{\circ} \mathrm{C}$. Batch cultures were gently mixed twice a day by hand, which gave the most reliable results compared to the use of several other mixing devices. Axenic algal cultures were checked for bacterial contamination at least once a week by epifluorescence microscopy after staining with acridine orange.

Continuous culture systems. Continuous culture experiments were conducted with Ditylum brightwellit (Table 1). The $900 \mathrm{ml}$ cultures were held at $13.0 \pm 0.2^{\circ} \mathrm{C}$ under a $16 / 8 \mathrm{~h} \mathrm{light/dark}$ regime, receiving 100 to $125 \mu \mathrm{mol}$ photons $\mathrm{m}^{-2} \mathrm{~s}^{-1}$ during the light period. Autoclaved, aged, nutrient-poor seawater was enriched with sterile $\mathrm{NaHCO}_{3}(2.7 \mathrm{mM}$ final concentration), $\mathrm{NaSiO}_{3}(300 \mu \mathrm{M})$, trace metals and vitamins (Brussaard et al. 1997). Phosphorus-limited media contained $3 \mu \mathrm{M}$ $\mathrm{NaH}_{2} \mathrm{PO}_{4}$ and $300 \mu \mathrm{M}$ nitrogen $\left(\mathrm{NaNO}_{3}\right.$ and $\mathrm{NH}_{4} \mathrm{Cl}$ 
at $150 \mu \mathrm{M}$ each). Nitrogen-limited media contained $50 \mu \mathrm{M} \mathrm{N}\left(\mathrm{NaNO}_{3}\right.$ and $\mathrm{NH}_{4} \mathrm{Cl}, 25 \mu \mathrm{M}$ each) and $50 \mu \mathrm{M}$ $\mathrm{NaH}_{2} \mathrm{PO}_{4}$. The $\mathrm{pH}$ of the medium was adjusted to $8.0 \pm$ 0.1 . Cultures were mixed at $30 \mathrm{rpm}$ by a glass clapper hanging just above the bottom of the vessel. The cultures were allowed to run for at least 4 volume changes and were considered to be at steady state when algal cell concentrations (total and dead cells) showed no significant changes ( $<5 \%$ standard deviation) for at least $5 \mathrm{~d}$. Dilution rate $\left(D, \mathrm{~d}^{-1}\right)$ under $\mathrm{N}$ limitation was $0.22 \mathrm{~d}^{-1}$. Because a strong effect of the physiological state of the algal cells on algal lysis rates had been found for axenic $D$. brightwellii populations cultured in P-limited chemostats at $D$ between 0.28 and $0.42 \mathrm{~d}^{-1}$ (Brussaard et al. 1997), D under P limitation was chosen at the lower and the upper limit of this range $[0.24$ and $0.44 \mathrm{~d}^{-1}$ ). Ambient concentrations of the limiting nutrients at steady state were $<0.26 \mu \mathrm{M} \mathrm{PO}_{4}{ }^{3-}$ in the Plimited chemostats and $0.43 \mu \mathrm{M} \mathrm{NH}_{4}{ }^{+}$and $0.99 \mu \mathrm{M}$ $\mathrm{NO}_{3}{ }^{-}$in the $\mathrm{N}$-limited chemostat. Average cell volumes in axenic $D$. brightwellii cultures at steady state were $6000 \mu \mathrm{m}^{3}$ under P limitation and $25000 \mu \mathrm{m}^{3}$ under $\mathrm{N}$ limitation. Axenic algal continuous cultures at steady state received $10 \mathrm{ml} \mathrm{GF/C} \mathrm{Whatman} \mathrm{filtrate} \mathrm{containing}$ a mixed community of bacteria, generally selected in xenic batch cultures of $D$. brightwellii. Bacterial cell concentrations in the continuous cultures directly upon inoculation were around $0.1 \times 10^{6} \mathrm{ml}^{-1}\left( \pm 10 \mathrm{ng} \mathrm{C} \mathrm{ml}^{-1}\right)$.

After new steady states had been established ( 3 to 4 culture volume changes of the medium), the medium supply was stopped (by turning off the pump) to study the influence of bacteria on algal cell mortality under nutrient starvation (batch-mode cultures; Table 1). The results from these batch-mode starvation experiments were compared with the data on cell lysis kinetics of axenic cultures of Ditylum brightwellii (Brussaard et al. 1997).

Sampling and analyses. Algal cells were preferably counted every day, but at least once every $2 \mathrm{~d}$. Samples were taken 2 to $3 \mathrm{~h}$ into the light period, fixed with acid Lugol/glutaraldehyde solution ( $\mathrm{v} / \mathrm{v}$, final concentration 15 to $20 \%$ ), and counted by inverse light microscopy (Zeiss) after settling on the bottom of multiwell plates. At least 300 algal cells were counted. Cells with empty frustules were counted as dead. Since dead cells of Ditylum brightwellii often broke into parts; 2 end parts were counted as 1 dead cell. Batch experiments with $D$. brightwellii were ended after 1 mo or as soon as the percentage of dead cells had reached $>35 \%$ of total cell concentrations.

Specific algal growth $\left(\mu, \mathrm{d}^{-1}\right)$ and algal cell death rates $\left(\delta, \mathrm{d}^{-1}\right)$ at steady state in the chemostats were calculated according to Brussaard et al. (1997):

$$
\begin{aligned}
\delta=\frac{D \cdot y^{*}}{x^{*}} & =\frac{D \cdot(x+y)^{*}}{x^{*}}-D \\
\mu & =D+\delta
\end{aligned}
$$

where $D$ is the dilution rate, $x^{*}$ and $y^{*}$ are the concentrations of living and dead cells $\left(\mathrm{l}^{-1}\right)$ at steady state, and $(x+y)^{*}$ is the total algal cell concentration $\left(l^{-1}\right)$

Table 1. List of experiments performed in the present study. All experiments were performed without (axenic algal culture) and with (xenic cultures) addition of bacteria. The concentrations of the nutrients limiting algal growth presented here are at the start

\begin{tabular}{|c|c|c|c|c|c|}
\hline Type of experiment & $\begin{array}{l}\text { Type of nutrient } \\
\text { limiting algal growth }\end{array}$ & $\begin{array}{c}\text { Nutrient } \\
\text { concentration }(\mu M)\end{array}$ & $\begin{array}{l}\text { Buffered with } \\
20 \mathrm{mM} \text { HEPES }\end{array}$ & $\begin{array}{l}\text { pH during } \\
\text { experiment }\end{array}$ & Replicates \\
\hline $\begin{array}{l}\text { Batch } \\
\text { ('nutrient depletion') }\end{array}$ & $\begin{array}{l}\text { Phosphate } \\
\text { Phosphate } \\
\text { Ammonium } \\
\text { Nitrate }\end{array}$ & $\begin{array}{l}2.5 \\
10 \\
15 \\
15\end{array}$ & $\begin{array}{l}\text { No } \\
\text { No } \\
\text { No } \\
\text { No }\end{array}$ & $\begin{array}{l}8.0-8.7 \\
8.0-8.7 \\
8.0-8.7 \\
8.0-8.7\end{array}$ & $\begin{array}{l}\text { Duplicate } \\
\text { Duplicate } \\
\text { Duplicate } \\
\text { Duplicate }\end{array}$ \\
\hline $\begin{array}{l}\text { Batch } \\
\text { ('nutrient depletion') }\end{array}$ & $\begin{array}{l}\text { Phosphate } \\
\text { Phosphate } \\
\text { Ammonium } \\
\text { Nitrate }\end{array}$ & $\begin{array}{l}2.5 \\
10 \\
15 \\
15\end{array}$ & $\begin{array}{l}\text { Yes } \\
\text { Yes } \\
\text { Yes } \\
\text { Yes }\end{array}$ & $\begin{array}{l}8.0 \pm 0.1 \\
8.0 \pm 0.1 \\
8.0 \pm 0.1 \\
8.0 \pm 0.1\end{array}$ & $\begin{array}{l}\text { Single } \\
\text { Single } \\
\text { Single } \\
\text { Single }\end{array}$ \\
\hline $\begin{array}{l}\text { Continuous culture } \\
\text { ('nutrient limitation') }\end{array}$ & $\begin{array}{l}\text { Phosphate } \\
\text { Nitrogen (ammonium } \\
\text { and nitrate) }\end{array}$ & $\begin{array}{l}<0.3(3)^{\mathrm{a}} \\
<1.5(50)^{\mathrm{a}}\end{array}$ & $\begin{array}{l}\text { No } \\
\text { No }\end{array}$ & $\begin{array}{l}8.0-8.7 \\
8.0-8.7\end{array}$ & $\begin{array}{l}\text { Single } \\
\text { Single }\end{array}$ \\
\hline $\begin{array}{l}\text { Batch mode } \\
\text { ('nutrient starvation') }\end{array}$ & $\begin{array}{l}\text { Phosphate } \\
\text { Nitrogen (ammonium } \\
\text { and nitrate) }\end{array}$ & $\begin{array}{l}<0.3 \\
<1.5\end{array}$ & $\begin{array}{l}\text { No } \\
\text { No }\end{array}$ & $\begin{array}{l}8.0-8.7 \\
8.0-8.7\end{array}$ & $\begin{array}{l}\text { Single } \\
\text { Single }\end{array}$ \\
\hline
\end{tabular}
of the experiments (batch and batch-mode cultures) or at steady state (continuous cultures) 
For the batch experiments, specific algal growth rates $\left(\mu_{\mathrm{b}}, \mathrm{d}^{-1}\right)$ and cell death rates $\left(\delta_{\mathrm{b},} \mathrm{d}^{-1}\right)$ were calculated according to Brussaard et al. (1997) using the formula:

$$
\begin{gathered}
\delta_{\mathrm{b}}=\frac{\ln x_{t}-\ln x_{0}}{t \cdot\left(\frac{(x+y)_{t}-(x+y)_{0}}{y_{t}-y_{0}}-1\right)} \\
\mu_{\mathrm{b}}=\delta_{\mathrm{b}} \frac{(x+y)_{t}-(x+y)_{0}}{y_{t}-y_{0}}
\end{gathered}
$$

where $x$ is the concentration of living cells $\left(\mathrm{l}^{-1}\right),(x+y)$ is the total cell concentration $\left(\mathrm{l}^{-\mathrm{t}}\right)$, and $y$ is the concen-
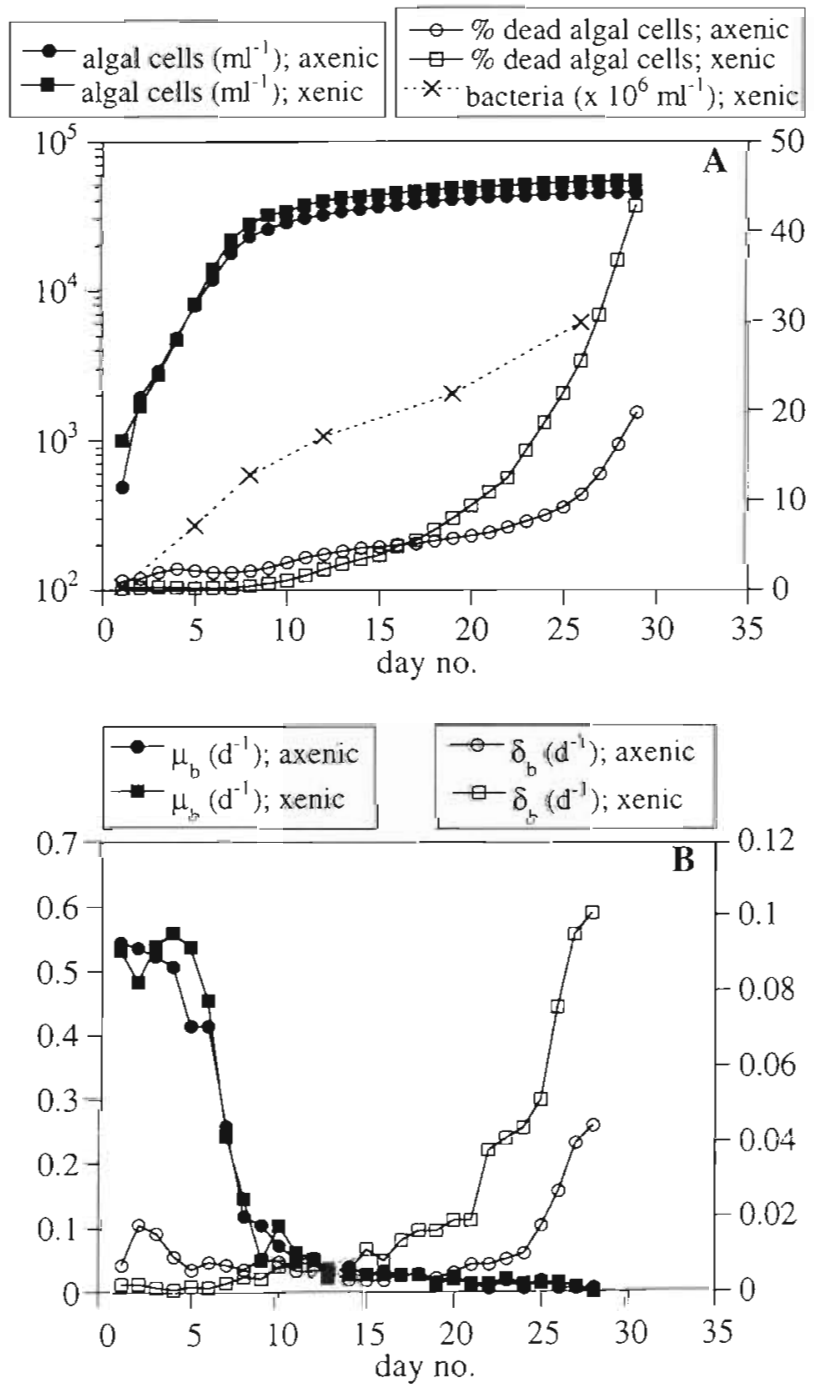

Fig. 1. Variations of (A) total algal cell concentrations, percentages of dead algal cells, bacterial cell concentrations and (B) specific algal growth $\left(\mu_{b}\right)$ and cell death rates $\left(\delta_{b}\right)$ in axenic and xenic batch cultures of Ditylum brightwellii with phosphate as the algal-growth-limiting nutrient. The ambient concentration of phosphate at the start of the experiments was $10 \mu \mathrm{M} .(0, \bullet)$ Axenic cultures; $(\square, \boldsymbol{a})$ xenic cultures tration of dead cells $\left(\mathrm{l}^{-1}\right)$. The total concentration of cells at time $t$ is represented by $(x+y)_{t}$ and the concentration of dead cells at time $t$ by $y_{t}$. Time intervals of $24 \mathrm{~h}$ were used to calculate $\mu_{\mathrm{b}}$ and $\delta_{\mathrm{b}}$.

Bacteria were counted on $0.2 \mu \mathrm{m}$ polycarbonate membrane filters (Poretics) by the acridine orange direct count method of Hobbie et al. (1977). After being filtered at $20 \times 10^{3} \mathrm{~Pa}$ over $0.2 \mu \mathrm{m}$ polysulfone filters (Acrodisc) and stored at $-50^{\circ} \mathrm{C}$ or $4^{\circ} \mathrm{C}$ (in the case of silicate), the ambient concentrations of dissolved inorganic nitrogen, phosphate and silicate were analyzed within 1 mo after collection on a TrAAcs 800 autoanalyzer (Technicon).
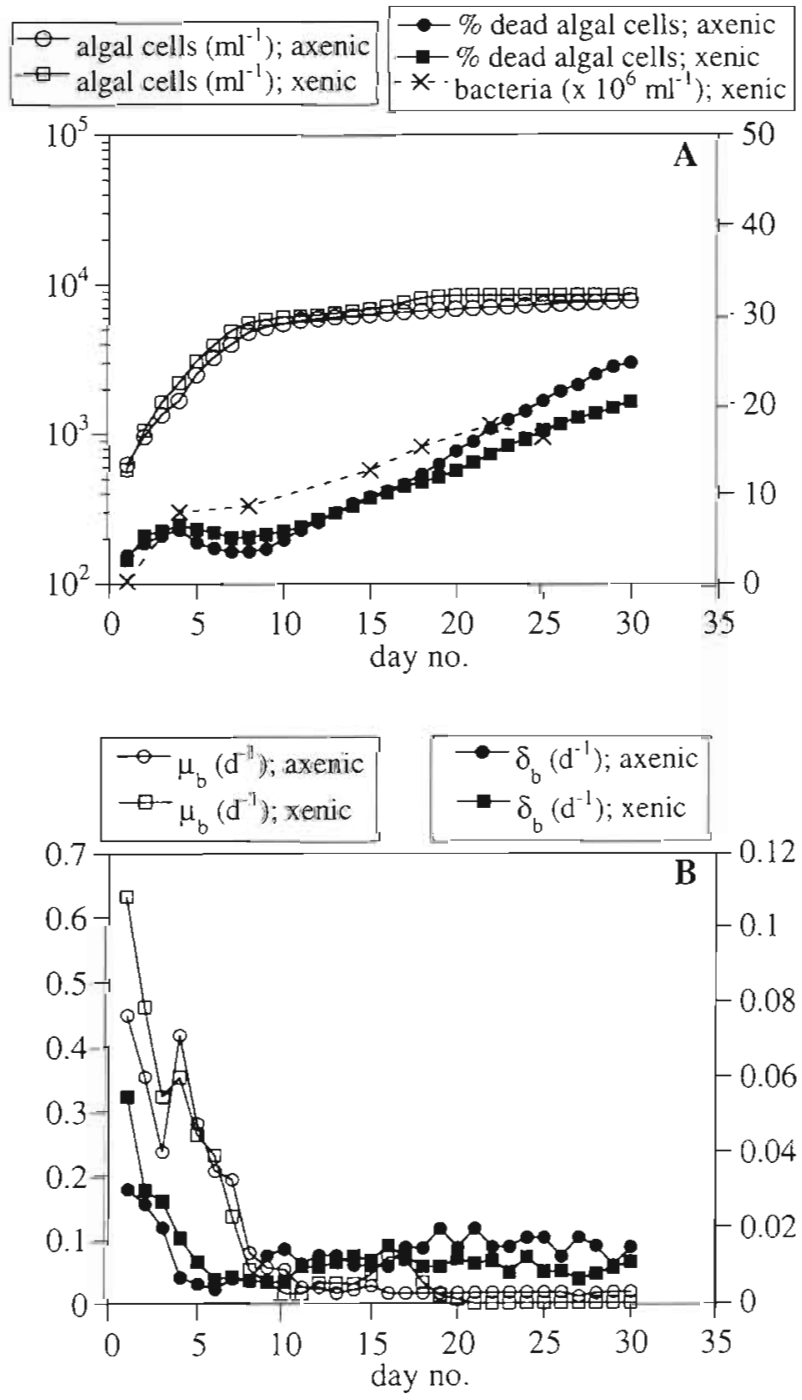

Fig. 2. Variations of (A) total algal cell concentrations, percentages of dead algal cells, bacterial cell concentrations and (B) specific algal growth $\left(\mu_{\mathrm{b}}\right)$ and cell death rates $\left(\delta_{\mathrm{b}}\right)$ in axenic and xenic batch cultures of Ditylum brightwellii with ammonium as the algal-growth-limiting nutrient. The ambient concentration of ammonium at the start of the experiments was $15 \mu \mathrm{M} .(0, \bullet)$ Axenic cultures; $(\square, \mathbf{\square})$ xenic cultures 


\section{RESULTS}

\section{Batch cultures}

Figs. $1 \& 2$ show representative examples of the variations in concentrations of total algal cells, percentages of dead algal cells, bacterial abundances, $\delta_{b}$ and $\mu_{\mathrm{b}}$ during batch culture experiments with phosphate or ammonium as the algal-growth-limiting nutrient (phosphate depletion and ammonium depletion, respectively). Bacterial cell concentrations were generally lower in the cultures with $N$ limiting algal growth compared to $\mathrm{P}$ limiting algal growth. Maximum bacterial biomass was 1.1 and $2.7 \mu \mathrm{g} \mathrm{C} \mathrm{m} \mathrm{Cl}^{-1}$ under ammonium and phosphate depletion, respectively.

Because the batch cultures were performed in duplicate, we were able to test the statistical significance of the different treatments on the algal cell death and growth kinetics. For each batch culture the specific algal cell death rates $\left(\delta_{b}, d^{-1}\right)$ of the last $10 \mathrm{~d}$ of the experiment were averaged. Maximum growth rates and gradients of the decline in algal growth rates were used to test the significance of bacterial presence on algal growth kinetics. Both the treatment using different types of nutrients limiting algal growth (phosphate, ammonium and nitrate) and the treatment without (axenic) and with (xenic) bacteria had significant effects on the average algal cell death rates (Table 2). No significant variance was found for the algal growth kinetics among the different treatments (data not shown). Bacterial addition to axenic batch cultures of Ditylum brightwellii led to increased $\delta_{b}$ when $\mathrm{P}$ was limiting algal growth, independent of the concentration of phosphate at the start of the experiments (Fig. 3). Under ammonium depletion, the presence of bacteria had no significant effect on $\delta_{\mathrm{b}}$, whereas under nitrate depletion a significant decline in $\delta_{\mathrm{b}}$ was recorded in the xenic compared to the axenic cultures (Fig. 3).

Table 2. Ditylum brightwellii. Statistical analysis of variance for specific cell death rates in (unbuffered) batch cultures ( $n=16)$. Experiments were performed in duplicate. Specific algal death rates were averaged over the last $10 \mathrm{~d}$ of the experiments. Treat $\mathrm{A}$ : treatment with different types of nutrients limiting algal growth (phosphate, ammonium and nitrate); Treat B: treatment without (axenic) and with (xenic) bacteria present in the algal cultures. Error: residual mean square giving an estimation of the error variance

\begin{tabular}{|lccccc|}
\hline Source & SS & df & MS & $F$ & $p$ \\
\hline Treat A & 0.00251 & 3 & 0.00084 & 28.352 & 0.00013 \\
Treat B & 0.00032 & 1 & 0.00032 & 10.863 & 0.01093 \\
Treat A $\times$ Treat B & 0.00099 & 3 & 0.00033 & 11.177 & 0.00312 \\
Error & 0.00024 & 8 & 0.00003 & & \\
& & & & & \\
\hline
\end{tabular}

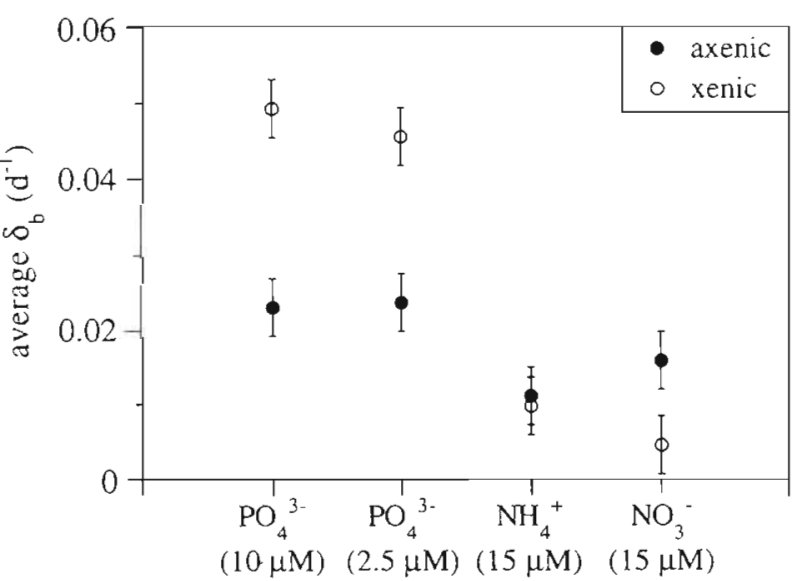

Fig. 3. Least squares means of specific algal death rates $\left(\delta_{b}\right.$, calculated according to Eq. 3) from duplicate batch culture experiments with phosphate, ammonium or nitrate as the algal-growth-limiting nutrient. Concentrations of limiting nutrients at the start of the experiments were 10 and $2.5 \mu \mathrm{M}$ phosphate, and $15 \mu \mathrm{M}$ ammonium and $15 \mu \mathrm{M}$ nitrate, respectively. For each batch culture, the algal death rates were averaged over the last $10 \mathrm{~d}$ of the experiments to allow statistical analysis. ( ) Axenic algal cultures; (O) xenic (containing algae and bacteria) cultures. Overall standard errors are based on the residual mean square (error) presented in Table 2

\section{Continuous cultures}

In contrast to batch cultures, chemostats represent growth conditions under nutrient limitation with a restricted but continuous supply of the limiting nutrient. Organisms cultured in chemostats adapt to nutrient limitation, resulting in balanced growth (steady state). Addition of bacteria to algal continuous cultures can be expected to disturb algal steady state because bacteria will compete with algae for the limiting nutrient.

Upon inoculating continuous cultures of Ditylum brightwellii with bacteria, new steady states established after several volume changes. Specific algal cell death rates at the newly established situations of balanced growth $\left(\delta, \mathrm{d}^{-1}\right)$ were comparable to $\delta$ at axenic steady states (Fig. 4). However, algal cell mortality in the P-limited cultures firstly increased 2 -fold directly upon inoculation with bacteria (max. $\delta=0.108$ and $0.013 \mathrm{~d}^{-1}$ at $D=0.24$ and 0.44 $\mathrm{d}^{-1}$, respectively). For $D=0.24 \mathrm{~d}^{-1}$ this resulted finally in a 2 -fold decrease in algal cell concentration (Fig. 4). Algal cell concentration under $\mathrm{N}$ limitation had increased slightly (Fig. 4, $D=0.22 \mathrm{~d}^{-1}$ ), whereas the diameter of the algal cells had become smaller (up to 2-fold) during the establishment of the new equilibrium (Fig. 4). Bacter- 


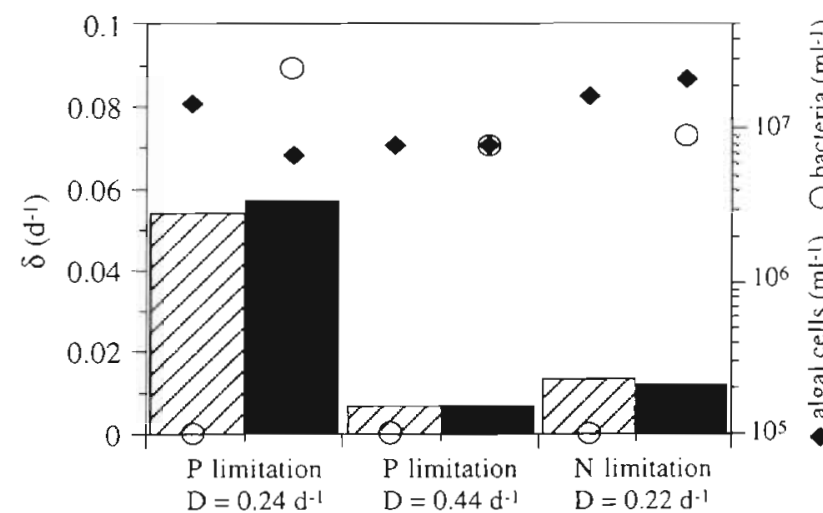

Fig. 4. Total algal cell concentrations of Ditylum brightwellii, bacterial cell concentrations and specific algal cell death rates ( $\delta$ ) during steady state in P-and N-limited continuous cultures. Algal cell death rates were calculated according to Eq. (1). Steady state growth rates $(\mu=\delta+D)$ were 0.30 and $0.45 \mathrm{~d}^{-1}$ under $\mathrm{P}$ limitation and $0.23 \mathrm{~d}^{-1}$ under $\mathrm{N}$ limitation. Striped bars represent the axenic cultures and black bars the xenic cultures

ial abundance reached highest levels under P limitation at $D=0.24 \mathrm{~d}^{-1}$ (Fig. 4). Upon addition of bacteria, the ambient concentration of ammonium in the $\mathrm{N}$ limited chemostat decreased from 0.45 to $0.15 \mu \mathrm{M}$, after which it increased again to $0.3 \mu \mathrm{M}$. Under P limitation, no such strong fluctuations were observed. Ambient concentrations of phosphate were 0.15 and $0.27 \mu \mathrm{M}$ at $D=0.24$ and $0.44 \mathrm{~d}^{-1}$, respectively.

Because specific algal growth rate $(\mu)$ is the sum of $D$ $+\delta$ (Brussaard et al. 1997), we will refer to $\mu$ instead of $D$ below. Under P limitation, $\mu$ was 0.30 and $0.45 \mathrm{~d}^{-1}$, and under $\mathrm{N}$ limitation it was $0.23 \mathrm{~d}^{-1}$.

\section{Batch-mode starvation cultures}

Starvation represents a situation with insignificant levels of the limiting nutrient to start with and during which there is no supply of nutrient. Brussaard et al. (1997) reported for axenic populations of Ditylum brightwellii that the growth rates prior to $\mathrm{P}$ starvation affected algal cell death kinetics. The starvation experiments were therefore conducted with cultures preconditioned under well-defined growth conditions in $\mathrm{N}$ - or P-limited continuous cultures. Fig. 5 shows that the impact of bacteria on algal death response under $\mathrm{P}$ starvation was influenced by the growth rate of the Plimited continuous culture to which the algal population was preconditioned prior to starvation. Bacteria were found to reduce the survival of the P-starved algal population precultured at $\mu=0.45 \mathrm{~d}^{-1}$ compared to the axenic control, as clearly represented by the cumulative representation of $\delta_{\mathrm{b}}$ (Fig. 5A). Average $\delta_{\mathrm{b}}$
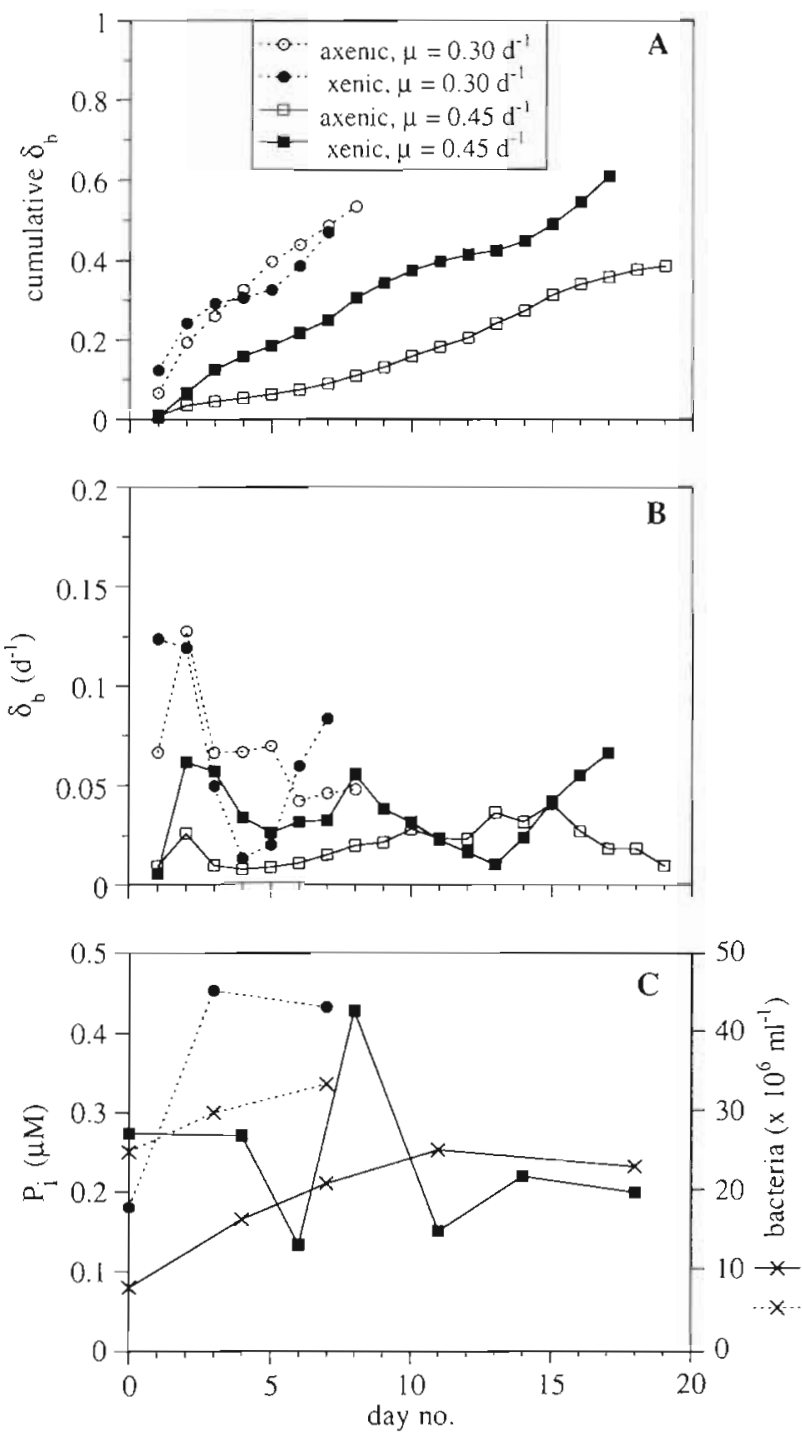

Fig. 5. Ditylum brightwellii. Influence of bacteria on cell death kinetics during $\mathrm{P}$ starvation. Cultures had been preconditioned in axenic and bacteria-containing (xenic) P-limited continuous cultures at steady state growth rates of 0.30 and $0.45 \mathrm{~d}^{-1}$ prior to starvation. (A) Cumulative representation of algal cell death $(B)$ specific algal cell death rates $\left(\delta_{b}\right)$. (C) Bacterial abundance (broken and solid lines represent preconditioning at $\mu=0.30$ and $0.45 \mathrm{~d}^{-1}$, respectively) and ambient phosphate concentrations ( $\mu \mathrm{M})$ in the xenic cultures

over the whole experimental time period was $0.020 \pm$ 0.010 for the axenic and $0.036 \pm 0.018 \mathrm{~d}^{-1}$ for the xenic cultures. No differences in survival of the algal population between axenic and xenic cultures under P starvation were recorded when preconditioned at $\mu=0.30 \mathrm{~d}^{-1}$ (Fig. 5A). For both treatments average $\delta_{h}$ over the whole experimental time period was $0.067 \mathrm{~d}^{-1}$. Oscillating patterns in $\delta_{\mathrm{b}}$ were observed for both growth rates (Fig. 5B). Preconditioned at $\mu=0.30 \mathrm{~d}^{-1}$, ambient concentration of the limiting nutrient phosphate 
increased directly after the start of the experiment to $0.45 \mu \mathrm{M}$ on Day 3 (Fig. $5 \mathrm{C}$ ). At $\mu=0.45 \mathrm{~d}^{-1}$ an increase in ambient concentration of phosphate was recorded 5 d later on Day 8 (Fig. 5C). Although bacterial cell concentrations reached highest levels in the cultures preconditioned at $\mu=0.30 \mathrm{~d}^{-1}$ (Fig. 5C), maximum bacterial biomasses were comparable for both growth rates $\left(3.5\right.$ and $3.0 \mu \mathrm{g} \mathrm{C} \mathrm{ml}^{-1}$ for $\mu=0.30$ and $0.45 \mathrm{~d}^{-1}$, respectively).

Survival of N-starved Ditylum brightwellii populations preconditioned at $\mu=0.23 \mathrm{~d}^{-1}$ was, after $10 \mathrm{~d}$, positively affected by bacteria (Fig. $6 \mathrm{~A}$ ). Average $\delta_{b}$ of the xenic culture $\left(0.011 \pm 0.006 \mathrm{~d}^{-1}\right)$ was more than 2 -fold smaller than of the axenic cultures. Bacterial presence resulted in reduced $\delta_{\mathrm{b}}$ after the first week of $\mathrm{N}$ starvation compared to axenic culture conditions (Fig, 6B). Ambient concentration of ammonium increased strongly after Day 7 to $1.8 \mu \mathrm{M}$ on Day 10 (Fig. 6C). Bacterial cell concentrations were relatively low (Fig. 6C) and had already reached their maximum after $3 \mathrm{~d}$ $\left(\approx 1.5 \mu \mathrm{g} \mathrm{C} \mathrm{ml} l^{-1}\right)$.

\section{DISCUSSION}

\section{Phosphorus as algal-growth-limiting nutrient}

Our results on phytoplankton-bacteria interactions in batch cultures and continuous cultures with phosphate as the algal-growth-limiting nutrient are consistent with the literature (Rhee 1972, Currie \& Kalff 1984, Bratbak \& Thingstad 1985, Bratbak 1987). In the P-limited continuous cultures, lower dilution rates led to less algae and more bacteria, due to competition for the limiting phosphate. The present study, however, is the first report actually recording algal cell death rates during such competition experiments. Resulting from competition for phosphate, specific cell death rates of Ditylum brightwellii increased upon inoculation with bacteria. Algal cell numbers declined as a result until bacteria became limited by a substrate other than phosphate, very likely organic carbon (Rhee 1972 , Bratbak 1987, Caron et al. 1988).

Both organic components released through algal cell lysis and organic carbon supplied by photosynthetic extracellular release (PER) may serve as C sources for bacteria (Ignatiades \& Fogg 1973, Myklestad 1977. Larsson \& Hagström 1979, Wolter 1982, Bratbak \& Thingstad 1985, Riemann \& Søndergaard 1986, Obernosterer \& Herndl 1995, Brussaard et al. 1996). Assuming a bacterial growth efficiency of 0.33 , and the algal cellular C under P limitation to be $240 \mathrm{pg} \mathrm{C}$ cell $^{-1}$ (Strathmann 1967), the organic carbon released through algal cell lysis at steady state in the P-limited continuous cultures was highest $(7.7$ times) at the
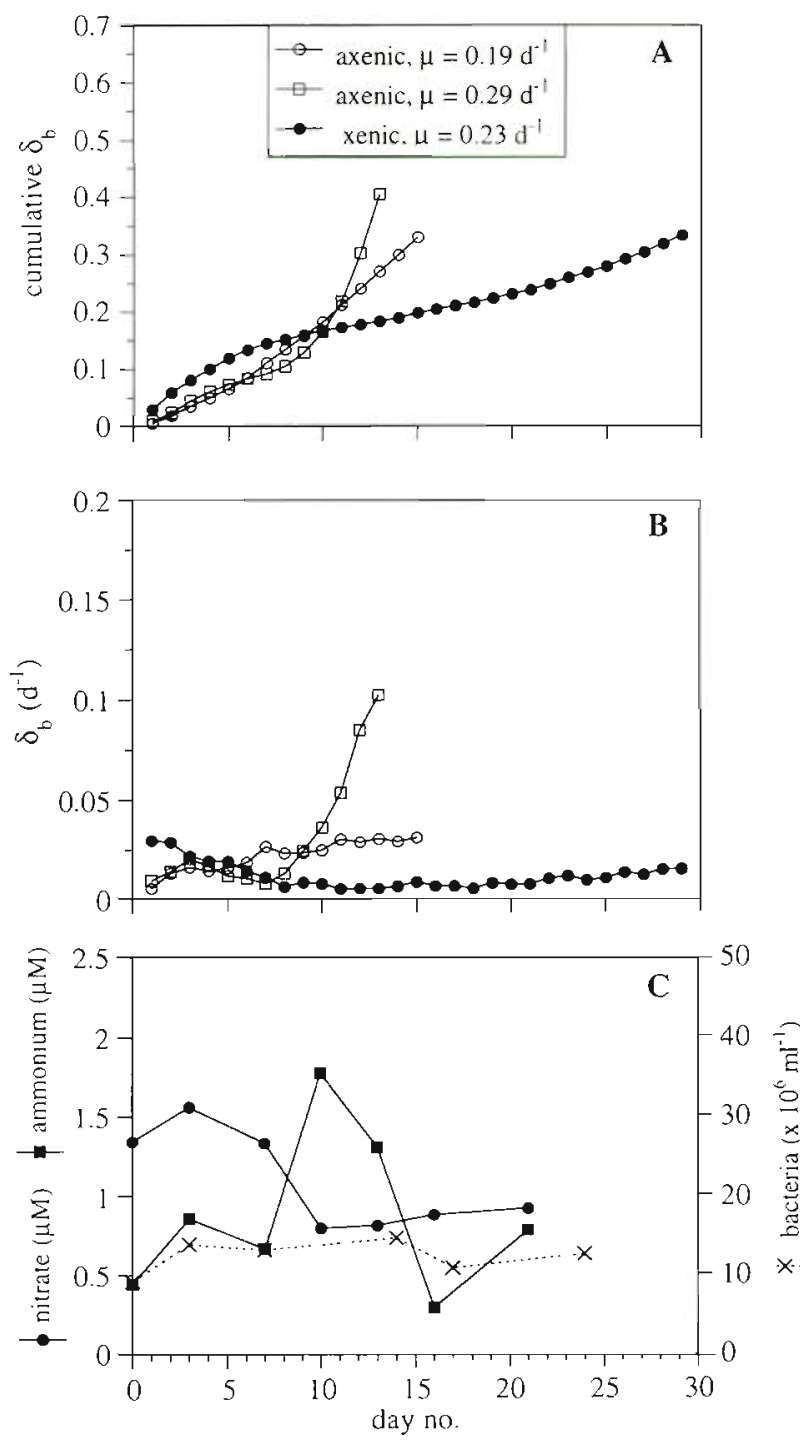

Fig. 6. Ditylum brightwellii. Influence of bacteria on cell death kinetics during $\mathrm{N}$ starvation. Cultures had been preconditioned in axenic and bacteria-containing (xenic) N-limited continuous cultures at $\mu=0.23 \mathrm{~d}^{-1}$ prior to starvation. (A) Cumulative representation of algal cell death; (B) specific algal cell death rates $\left(\delta_{b}\right)$. (C) Bacterial abundance and ambient concentrations of ammonium and nitrate in the xenic cultures. Because the xenic cultures had been preconditioned at slightly different growth rates in the $\mathrm{N}$-limited chemostat than the axenic cultures, data were compared with 2 axenic cultures precultured at somewhat lower $\left(\mu=0.19 \mathrm{~d}^{-1}\right)$ and higher $\left(\mu=0.29 \mathrm{~d}^{-1}\right)$ steady state growth rates

lower growth rate $\left(\mu=0.30 \mathrm{~d}^{-1}\right)$. However, algal cell lysis as a source of organic carbon for bacteria was insuffient to account for the total bacterial $\mathrm{C}$ demand. Organic carbon supply by PER may have been another C source for bacteria.

By turning off the medium supply to the continuous cultures, the cultures became exhausted in phosphate 
(P starvation). As argued above, bacteria were probably already $C$ limited prior to starvation. Bacterial utilization of relatively $P$ rich lysed algal cellular components during $P$ starvation led therefore to remineralization of phosphate (Bratbak 1987, Jürgens \& Güde 1990). Above a certain concentration, it can be expected that remineralized phosphate will be readily taken up by the P-deficient algal cells, which may lead to reduced algal cell death. As soon as the concentration of phosphate becomes too low, $\mathrm{P}$ deficiency in algal cells and subsequently algal cell death will increase again. The oscillations in $\delta_{\mathrm{b}}$ of Ditylum brightwellii seem to reflect variations in the concentration of remineralized phosphate and thus reflect alternations in the degree of bacterial $\mathrm{P}$ and $\mathrm{C}$ limitation. The reduced survival of the $D$. brightwellii population in the cultures preconditioned at the higher growth rate $\left(\mu=0.45 \mathrm{~d}^{-1}\right)$ suggests that the increases in $\delta_{b}$ due to competition for phosphate with bacteria were more important than the reductions in $\delta_{\mathrm{b}}$ due to algal utilization of periodically bacterial regenerated phosphate. Preconditioned at the lower growth rate $\left(\mu=0.30 \mathrm{~d}^{-1}\right)$, however, fluctuations in $\delta_{\mathrm{b}}$ compensated each other for no differences in survival abilities were recorded for the axenic and xenic algal populations. It has to be noted that maximum values of $\delta_{\mathrm{b}}$ in the xenic cultures adapted to $\mu=0.45 \mathrm{~d}^{-1}$ were still lower than those in cultures held at $\mu=0.30 \mathrm{~d}^{-1}$ Enhanced $\delta_{b}$ due to the presence of bacteria was also observed in the batch culture experiments with $P$ as the algal-growth-limiting nutrient. In batch cultures, algal growth rates were relatively high prior to exhaustion of the limiting nutrient (exponential growth versus stationary phase). Apparently, D. brightwellii cells which had been growing at higher rates were not so well equipped to compete with bacteria for phosphate as the algal populations preconditioned at lower growth rates.

\section{Nitrogen as algal-growth-limiting nutrient}

Upon inoculation with bacteria in N-limited continuous culture at $\mu=0.23 \mathrm{~d}^{-1}$, algal cell concentration did not decline as expected (Bratbak \& Thingstad 1985). Instead, algal cell size reduced (cells had become thinner). This increased their surface:volume ratios (up to 1.3) and most likely lowered their cellular $N$ demand, allowing the algal cells to grow at $\mu=0.23 \mathrm{~d}^{-1}$ without a decline in population size. Models on interactions between phytoplankton and bacteria under $\mathrm{N}$ limitation (letswaart \& Flynn 1995) should include such adaptations of algal cells to increased $N$ deficiency.

The present study shows that, in contrast to xenic cultures with $\mathrm{P}$ as the algal-growth-limiting nutrient, no reduced survival of Ditylum brightwellii populations was observed in xenic cultures with $\mathrm{N}$ as the algal-growth-limiting nutrient compared to axenic controls. In the ammonium-depleted batch cultures, there was no significant effect of bacteria on algal mortality kinetics. Under nitrate depletion, algal cell death rates actually declined in the presence of bacteria compared to the axenic control. Reduced algal mortality was also observed under $\mathrm{N}$ starvation. Accumulation of ammonium after the first week of $\mathrm{N}$ starvation indicates that bacteria were limited in their growth by carbon (Caron et al. 1988, Goldman \& Dennett 1991). The lower bacterial biomass in cultures with $N$ compared to cultures with $\mathrm{P}$ as the algal-growth-limiting nutrient (both batch and continuous cultures) indicates that the bacterial population was more $\mathrm{C}$ limited under $\mathrm{N}$ - than under P-deficient culture conditions. Degradation of relatively $\mathrm{N}$ rich algal lysis products by the $\mathrm{C}$-limited bacteria probably resulted in the release of ammonium, which very likely was utilized by the $\mathrm{N}$-deficient D. brightwellii cells.

\section{Ecological relevance}

The paradox that phytoplankton stressed by the lack of limiting nutrient stimulate growth of their competitors, as described by Bratbak \& Thingstad (1985), did not apply to $\mathrm{N}$ deficiency. Under $\mathrm{N}$ deficiency, both algae and bacteria can actually benefit from each other. Axenic cultures of Ditylum brightwellii have been found to withstand $N$ starvation better than P starvation, especially when preconditioned at a lower growth rate (Brussaard et al. 1997). The results in the present study show that these nutrienttype specific differences in algal death response to nutrient starvation are even more pronounced with bacteria present.

Since $N$ starvation generally occurs in natural marine pelagic ecosystems, prolonged survival of $\mathrm{N}$ starved populations of the neritic diatom Ditylum brightwellii due to bacterial mineralization of ammonium can give the algal species a competitive advantage. Besides algal mortality and PER responses to nutrient starvation, bacterial nutrient requirements also influence algal-bacterial interactions. The relatively higher bacterial requirements for $\mathrm{P}$ than for $\mathrm{N}$ (assuming $C: N: P=106: 16: 1$ and 40:10:1 for algae and bacteria respectively; Kirchman 1994), compared to phytoplankton, imply higher remineralization rates for ammonium than for phosphate, which in turn may enhance phytoplankton survival.

Factors responsible for the different death responses of nutrient-depleted phytoplankton (e.g. differences in intrinsic rates of organic carbon supply through algal 
cell lysis, in rates and molecular composition of exudation of photosynthetically fixed carbon, and in algal cell size) are very likely species-specific. Under phosphate depletion, the presence of bacteria enhanced $\delta_{\mathrm{b}}$ of Ditylum brightwellii to a lesser extent than of Skeletonema costatum (maximum $\delta_{\mathrm{b}}$ of $0.21 \mathrm{~d}^{-1}$, calculated from data published by Bratbak (1987) according to Eq. (2)]. Under axenic growth conditions the cultures of $D$. brightwellii and $S$. costatum had comparable $\delta_{b}$. A pilot study on the diatom Lauderia borealis showed that, in the presence of bacteria and compared to $D$. brightwellii, average algal death rates over a $3 \mathrm{wk}$ experimental time period were about 2 -fold higher in phosphate-depleted batch cultures (maximum $\delta_{\mathrm{b}}$ of $0.28 \mathrm{~d}^{-1}$ ) but 1.5 times lower under ammonium depletion (maximum $\delta_{b}$ of $0.04 \mathrm{~d}^{-1}$; unpubl. data). These results are consistent with the lower death rates for $L$. borealis compared to $D$. brightwellii when cultured in the presence of bacteria in ammonium-limited chemostats (average $\delta=0.001 \mathrm{~d}^{-1}$ with $\mu$ ranging from 0.09 to $0.60 \mathrm{~d}^{-1}$, calculated from data kindly provided by $W$. Stolte). The data mentioned above suggest that species-specific differences in the response of nutrientdeficient phytoplankton to the presence of bacteria do exist (although at this point it cannot be ruled out that inter-clonal variations may be as large as the variations found between species). Species-specific differences in algal cell mortality due to the presence of bacteria imply that bacteria may affect phytoplankton succession significantly, with potentially large differences in algal response for the various types of algal-growthlimiting nutrients.

\section{Conclusions}

The present experiments studying the influence of bacteria on cell death kinetics of Ditylum brightwellii under culture conditions with either $N$ or $P$ limiting algal growth showed that, compared to axenic cultures, enhanced mortality was only recorded for the P-deficient $D$. brightwellii populations (Table 3). Bacterial inoculation into cultures of $D$. brightwellii where $\mathrm{N}$ was the algal-growth-limiting nutrient either had no effect on algal mortality or indirectly reduced algal cell mortality and subsequently prolonged the survival of the algal population (Table 3). Bacterially regenerated ammonium was very likely utilized by $\mathrm{N}$ starved cultures of $D$. brightwellii, thereby prolonging survival of the algal population. It is concluded from this study that bacteria do influence phytoplankton cell death kinetics, but that the degree of impact largely depends on the type of nutrient limiting algal growth and the culture history of the algal populations.
Table 3. Ditylum brightwellii. Summary of cell death responses in the presence of bacteria to various culture conditions under nitrogen $(\mathrm{N})$ or phosphorus $(\mathrm{P})$ deficiency. Symbols: increase $(+)$, decrease $(-)$, or no change $(=)$ in algal cell mortality compared to axenic controls. Starved batch-mode cultures were preconditioned in $\mathrm{N}$ - or P-limited continuous cultures. n.e.: no experiment was performed. 'Algal death rates were comparable to axenic controls when ammonium limited algal growth, whereas death rates decreased when nitrate limited algal growth. " During establishment of new steady states upon bacterial inoculation, algal cell death rates first increased

\begin{tabular}{|lccc|}
\hline \multicolumn{1}{|c}{ Preconditioned at } & $\mathrm{N}$ & $\mathrm{P}$ \\
\hline $\begin{array}{l}\text { Batch } \\
\text { ('nutrient depletion') }\end{array}$ & $=$ or $-^{-}$ & + \\
$\begin{array}{l}\text { Chemostat } \\
\text { ('nutrient limitation') }\end{array}$ & $=$ & $=\cdot$ \\
$\begin{array}{llll}\text { Batch mode } \\
\text { ('nutrient starvation') }\end{array}$ & $\mu \leq 0.30 \mathrm{~d}^{-1}$ & n.e. & $=$ \\
\hline
\end{tabular}

Acknowledgements. Thanks to Karel Bakker for nutrient analyses, and to Willem Stolte for kindly providing data on Lauderia borealis. We thank Han Lindeboom, Lubbert Dijkhuizen, Gerhard Herndl, and 2 anomynous reviewers for their comments on the manuscript. This is NIOZ publication no. 3198.

\section{LITERATURE CITED}

Biddanda BA (1988) Microbial aggregation and degradation of phytoplankton-derived detritus in seawater. II. Microbial metabolism. Mar Ecol Prog Ser 42:89-95

Bjornsen PK (1988) Phytoplankton exudation of organic matter: why do healthy cells do it? Limnol Oceanogr 33: $151-154$

Bratbak G (1987) Carbon flow in an experimental microbial ecosystem. Mar Ecol Prog Ser 36:267-276

Bratbak G, Thingstad TF (1985) Phytoplankton-bacteria interactions: an apparent paradox? Analysis of a model system with both competition and commensalism. Mar Ecol Prog Ser 25:23-30

Brussaard CPD, Gast GJ, van Duyl FC, Riegman R (1996) Impact of phytoplankton bloom magnitude on a pelagic microbial food web. Mar Ecol Prog Ser 144:211-221

Brussaard CPD, Noordeloos AAM, Riegman R (1997) Autolysis kinetics of the marine diatom Ditylum brightwellii (Bacillariophyceae) under limitation and starvation of nitrogen and phosphorus. J Phycol 33(6):980-987

Brussaard CPD, Riegman R, Noordeloos AAM, Cadée GC, Witte $H_{1}$ Kop AJ, Nieuwland G, van Duyl FC, Bak RPM (1995) Effects of grazing, sedimentation and phytoplankton cell lysis on the structure of a coastal pelagic food web. Mar Ecol Prog Ser 123:259-271

Caron DA, Goldman JC, Dennett MR (1988) Experimental demonstration of the roles of bacteria and bacterivorous protozoa in plankton nutrient cycles. Hydrobiologia 159 . $27-40$

Christoffersen K, Riemann B, Hansen LR, Klysner A, Sorensen HB (1990) Qualitative importance of the microbial loop and plankton community structure in a eutrophic lake during a bloom of cyanobacteria. Microb Ecol 20: $253-272$ 
Currie DJ, Kalff J (1984) Can bacteria outcompete phytoplankton for phosphorus? A chemostat test. Microb Ecol 10:205-216

Fukami K, Simidu U, Taga N (1981) Fluctuation of the communities of heterotrophic bacteria during the decomposition process of phytoplankton. J Exp Mar Biol Ecol 55:171-184

Garber JH (1984) Laboratory study of nitrogen and phosphorus remineralization during the decomposition of coastal plankton and seston. Estuar Coast Shelf Sci 18:685-702

Goldman JC, Dennett MR (1991) Ammonium regeneration and carbon utilization by marine bacteria grown on mixed substrates. Mar Biol 109:369-378

Hansen L, Krog GF, Sondergaard M (1986) Decomposition of lake phytoplankton. I. Dynamics of short-term decomposition. Oikos 46:37-44

Hobbie JE, Daley RJ, Jasper S (1977) Use of nucleopore filters for counting bacteria by fluorescence microscopy. Appl Environ Microbiol 33:1225-1228

Ietswaart T, Flynn KJ (1995) Modelling interactions between phytoplankton and bacteria under nutrient-regenerating conditions. J Plankton Res 17:729-744

Ignatiades L, Fogg GE (1973) Studies on the factors affecting the release of organic matter by Skeletonema costatum (Greville) Cleve in culture. J Mar Biol Assoc UK 53: 937-956

Jürgens K, Güde H (1990) Incorporation and release of phosphorus by planktonic bacteria and phagotrophic flagellates. Mar Ecol Prog Ser 59:271-284

Kirchman DL (1994) The uptake of inorganic nutrients by heterotrophic bacteria. Microb Ecol 28:225-271

Kirchman DL, Keil RG, Wheeler PA (1990) Carbon limitation of ammonium uptake by heterotrophic bacteria in the subarctic Pacific. Limnol Oceanogr 35:1258-1266

Lancelot C, Billen G (1985) Carbon-nitrogen relationships in nutrient metabolism of coastal marine ecosystems. Adv Aquat Microbiol 3:263-321

Larsson U. Hagström A (1979) Phytoplankton exudate release as an energy source for the growth of pelagic bacteria.

Editorial responsibility: William Li,

Dartmouth, Nova Scotia, Canada
Mar Biol 52:199-206

Mague TH, Friberg E, Hughes DJ, Morris I (1980) Extracellular release of carbon by marine phytoplankton; a physiological approach. Limnol Oceanogr 25(2):262-279

Myklestad S (1977) Production of carbohydrates by marine planktonic diatoms. II. Influence of the N/P ratio in the growth medium on the assimilation ratio, growth rate, and production of cellular and extracellular carbohydrates by Chaetoceros affinis var. willei (Gran) Hustedt and Skeletonema costatum (Grev.) Cleve. J Exp Mar Biol Ecol 29: $161-179$

Myklestad S, Holm-Hansen O, Vårum KM, Volcani BE (1989) Rate of release of extracellular amino acids and carbohydrates from the marine diatom Chaetoceros affinis. J Plankton Res 11:763-773

Newell RC, Lucas MJ, Linley EAS (1981) Rate of degradation and efficiency of conversion of phytoplankton debris by marine microorganisms. Mar Ecol Prog Ser 6:123-136

Obernosterer I, Herndl GJ (1995) Phytoplankton extracellular release and bacterial growth: dependence on the inorganic N:P ratio. Mar Ecol Prog Ser 116:247-257

Rhee GY (1972) Competition between an alga and an aquatic bacterium for phosphate. Limnol Oceanogr 17:505-514

Riemann B, Sondergaard M (1986) Regulation of bacterial secondary production in two eutrophic lakes and in experimental enclosures. J Plankton Res 8:519-536

Rothhaupt KO (1992) Stimulation of phosphorus-limited phytoplankton by bacterivorous flagellates in laboratory experiments. Limnol Oceanogr 37:750-759

Strathmann RR (1967) Estimating the organic carbon content of phytoplankton from cell volume or plasma volume. Limnol Oceanogr 12:411-418

Thingstad T, Skjoldal EF, Bohne RA (1993) Phosphorus cycling and algal-bacterial competition in Sandsfjord, western Norway. Mar Ecol Prog Ser 99:239-259

Wolter K (1982) Bacterial incorporation of organic substances released by natural phytoplankton populations. Mar Ecol Prog Ser 7:287-295

Submitted: October 26, 1997, Accepted: October 27, 1997 Proofs received from author(s): February 26, 1998 